\section{Olha Sosik Оньга Сосік}

postgraduate student, Department of Fine Art Boris

Grinchenko Kyiv University

аспірантка кафеАри образотворчого мистецтва

Київського університету імені Бориса Грінченка

e-mail: olhasosik@gmail.com orcid.org/0000-0002-2450-1235

\title{
Ancient Egyptian and Antique Visions in the Art of Wilhelm Kotarbinski
}

\author{
Аавньоєгипетські й античні візії \\ у творчому доробку
Вільгельма Котарбінського
}

\begin{abstract}
Ancient Egyptian and antique visions in the art of the Ukrainian artist of Polish origin Wilhelm Kotarbinski during the late $19^{\text {th }}$ - the early $20^{\text {th }}$ century were reviewed in this paper. The example of the aforementioned subjects was used to outline the essence of stylistic transformations of the artist's works in the period of the spreading of artistic trends related to salon academism, decadence, and symbolism. It has been stated that the classical works "a la antique" and the elements of ancient Egyptian art of Hellenistic period, included into the treasury of world art during the Empire period, formed the basis of the artistic language of the historicism era when they were re-experienced and rethought by the artists who got the academic education by specialty. The same well-studied primary elements became the art material through which the artists "lived through" the latest philosophical and aesthetic impressions and put new layers of meanings into them.
\end{abstract}

Keywords: historical method, Egyptian and antique art, academism, decadence, symbolism, works of W. Kotarbinski, orientalism, antiquity.

Problem statement. The unique features of the art of Wilhelm Kotarbinski are in his appeal to the variety of subjects and stylistic techniques that were reigning in art during the entire $19^{\text {th }}$ century. With regard to the academic school in which the artistic language of the specified master has its roots, the subject of ancient civilizations was a core motif of his art. The artist kept returning to it at different periods of his stylistic searches and new means of expression. Addressing the Graeco-Roman and Egyptian art legacy as the fundamentals in the formation of harmonious forms, W. Kotarbinski aspired to reproduce the images of the past in the contemporary context. At the time being, the retrospective subject in the paintings of a famous Polish-Ukrainian artist remains poorly investigated and requires thorough analysis in terms of the leading art trends of that time.

Analysis of recent research works and publications. Materials adjacent to this research can be divided into specific studies relating to common issues of ancient art, and separate publications highlighting the specific aspects of W. Kotarbinski's works. For example, subjects of Ancient Egypt and antiquity often become the focus of art experts' attention. Among them, the important studies in terms of the subject specified, include the fundamental works by M. Mathieu "Art of Ancient Egypt" [6] and B. V. Polevoi "Art of Greece. The Ancient World" [9], together with the materials of the first volume of the "Common History of Art" edited by A. Chegodaev [15]. The publication adjacent to the above issues is the work by Ie. Gruzdiova "Study of the Culture of Ancient Egypt at the turn of the $19^{\text {th }}-20^{\text {th }}$ centuries" [2]. The latter deals with the causes of raising the interest in Egyptian culture as a cradle of European civilization.

Moreover, there are separate papers dedicated to works of W. Kotarbinski, in which the authors briefly review the subject of historical method in this artist's work. In particular, the valuable sources of facts are the articles by Doctor of Art History, Prof. L. Savitska, "A genius who knew what he did", [10] and "Wilhelm Kotarbinski in the art of his time”, [11] in which the researcher reviews crucial subjects and motives used in the artist's works. It should be also noted that an important component of this study was the catalog album of the artist's famous paintings prepared by the team of museum researchers, "Wilhelm Kotarbinski" [3]. It contains a huge number of his work reproductions known today. However, all the aforementioned studies have are rather of general and declarative character. Therefore, so far, no individual research has been dedicated to the artistic features of comprehending Egyptian and antique motives in W. Kotarbinski's art through the spectacle of the period style formation (transformations of academism, historical method, decadence, and symbolism). 


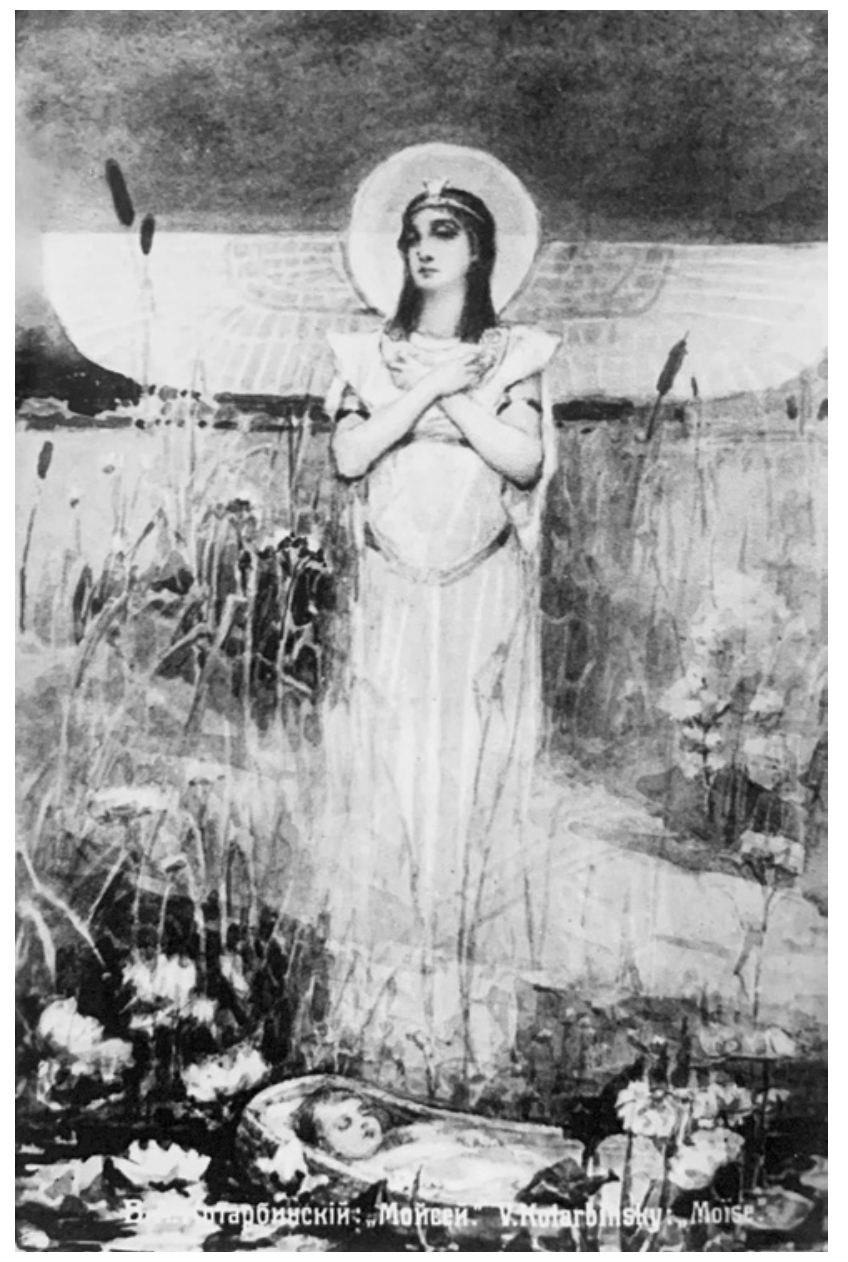

Objectives of the study: to analyze the features of the embodiment of new stylistic directions in the ancient Egyptian and antique studies of Wilhelm Kotarbinski.

Presentation of the main research material. The trends of the historical method, that spread in the European art of the $19^{\text {th }}$ century, became a response to the social and cultural crisis caused by technological and scientific progress. Fast industrialization and urbanization shifted the public value accents to pragmatism and ambition, having caused the change of its moral and social attitudes. Art due to the lack of time to adapt to the new reality, aspired to find stability in harmonious ideals of the past civilizations. Whereas, Ancient Egypt and the antique periods attracted special interest. However, these subjects did not gain wide popularity in the national art of the late $19^{\text {th }}$ - early $20^{\text {th }}$ centuries. The only artist who addressed these motives from time to time in his life was W. Kotarbinski, who graduated from the Roman Academy of St. Luke.

The history of admiration of Egyptian art has its roots as early as in the times of the conquest of Egypt by the Roman Empire. At that time, the Romans initiated active export and decoration of their cities with obelisks and took over the public fancy in Egyptian furniture, the shape of vessels, etcetera. For example, the first obelisks were brought by Emperor Augustus from Heliopolis and were installed on the arena of the Circus Maximus in Rome to serve as a sundial, and in front of the Temple of Caesar in Alexandria. One typical example is the obelisk on Sultanahmet Square

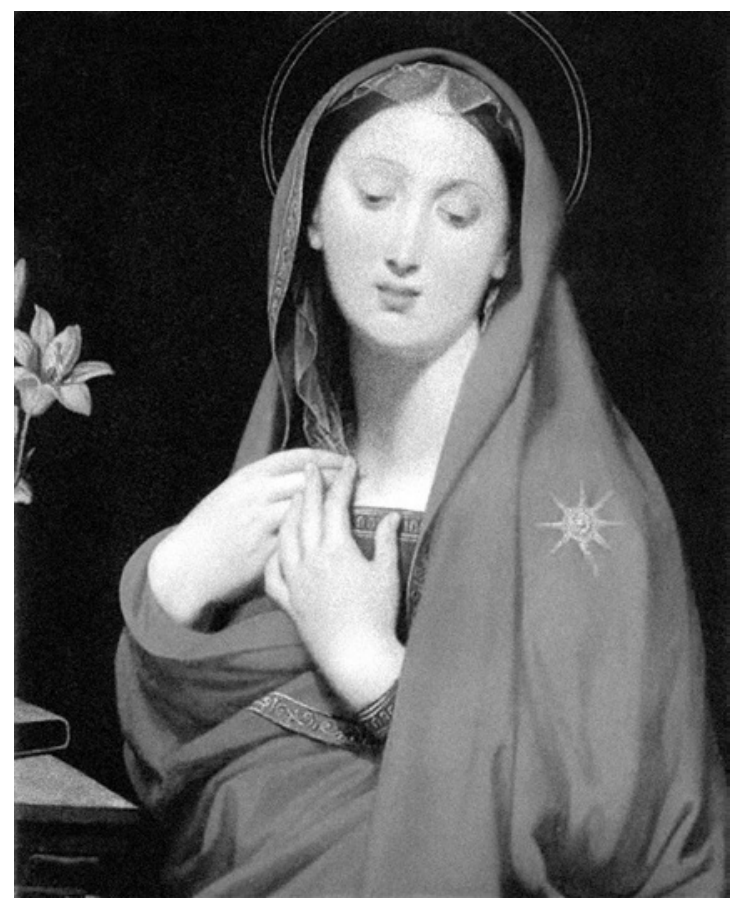

2. Jean-Auguste-Dominique Ingres. Virgin of the Adoption. 1858

1. Kotarbinskyi W. Moses. Date unknown

in the center of Constantinople, which kept influencing the imagination of artists, who were studying the heritage of great civilizations, for several generations.

The following interest in early civilizations occurred during the Renaissance, when the interest in Roman antiquity and, at the same time, in the Egyptian culture, returned. Then, a large number of researchers appeared, who tried to find a key to hieroglyphic script. Unfortunately, unsuccessful attempts to decipher this script, due to the erroneous thought that the hieroglyphs are "<...> neither letters nor syllables, but only ideographs, each of them hiding the certain $\langle\ldots>$ mystical notion", have, in the end, turned " $<\ldots>$ Egyptology studies to a sign of amateurism" [14, p. 27].

However, this only heated interest in Egyptian art and architecture, so during their voyage in this country, European travelers started sketching and copying inscriptions from ancient monuments. For example, Doctor of Art History, Prof. O. Shkolna states in her paper "Arabian art and the contemporary specifics of its research" that "The oriental has gradually become a synonym to 'refined', 'sophisticated', 'overseas', 'fancy"' [16, p. 121-122].

But the real explosion of interest in Orientalism on the European continent began after Napoleon's Campaign in 1798. Together with the emperor, a specially founded Committee of Sciences and Art was sent to Egypt, which included scientists from various fields of knowledge and artists, in particular, painters and writers. After taking possession of Cairo, Napoleon signed a decree 


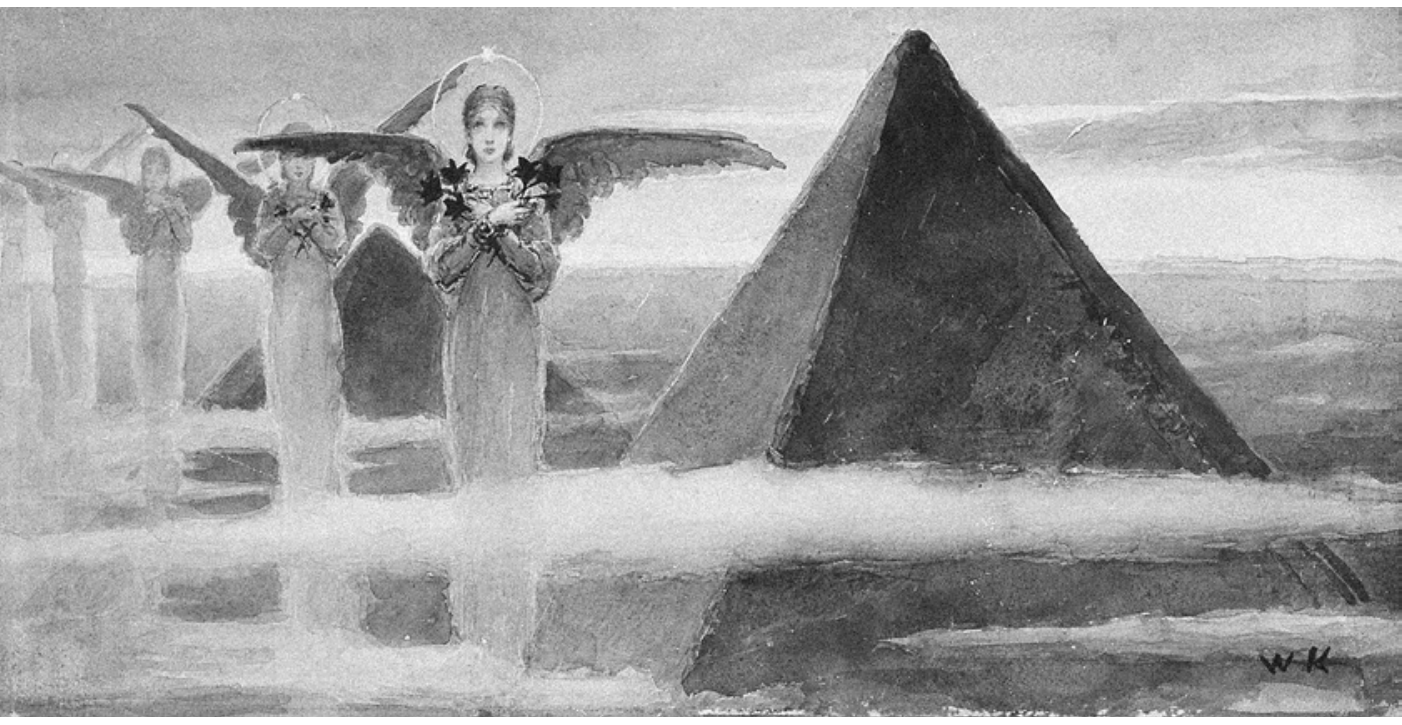

3. Kotarbinski W. Angels of the Pyramids. Date unknown on the foundation of the Institute of Egypt in that city, with its principal task to study and spread the cultural legacy of the country. Consequently, " $<\ldots>$ a large amount of archaeological data about the rulers $\langle\ldots\rangle$ was accumulated, and many sepulchers, $\langle\ldots\rangle$, temples, obelisks were attributed" [2, p. 275].

In the late $19^{\text {th }}$ century, the interest in Europe to the Egyptian culture, with its mystery and mysticism, increased significantly. D. Merezhkovsky wrote, "The $19^{\text {th }}$ century, $\langle\ldots\rangle$ is the era $\langle\ldots\rangle$ of tiresome need in new religious ideas" [7]. This was not least due to the feeling of the decline of the European civilization, which, on the one part, had firm roots but, on the other, stayed in a state of uncertainty concerning new vectors of its spiritual development. Numerous revolutions, new philosophical theories, scientific discoveries, and technical progress destroyed the habitual world view and, in the end, queried the existence of God. Positivist cognition, which was dominant in the $19^{\text {th }}$-century global paradigm, started provoking resistance in people's consciousness.

According to the statement by the philosopher Paul Valery, "An extraordinary shudder ran through the marrow of Europe. She felt in every nucleus of her mind that she was no longer the same, that she was no longer herself... the whole spectrum of intellectual light spread out its incompatible colors, illuminating with a strange and contradictory glow the death agony of the European soul." [1, p. 84]. Thus, the deep spiritual crisis of that period brought to life by the fragility of the habitual world and the eschatological presentiment of catastrophe, encouraged the society to look for support in the dualistic mythology of Ancient Egypt. In particular, in its stable symbolism, that was based on the understanding of the sense of life on the border of the two worlds, the living and the dead, and the senses brought by them: not reincarnation but the continuation of life in a different role, where the lower world beauty was just transferred to the upper one.

One of the first Ukrainian artists who addressed the Egyptian motives was Wilhelm Kotarbinski. As in the second half of the $19^{\text {th }}$ century, the oriental motives were mainly used in academic painting, and he was educated in such a school in Rome. However, in the Egyptian studies of W. Kotarbinski, the image component obtained the new tone, being enriched by the innovative stylistic "settings". Further, in the artist's works, oriental sciences passed through

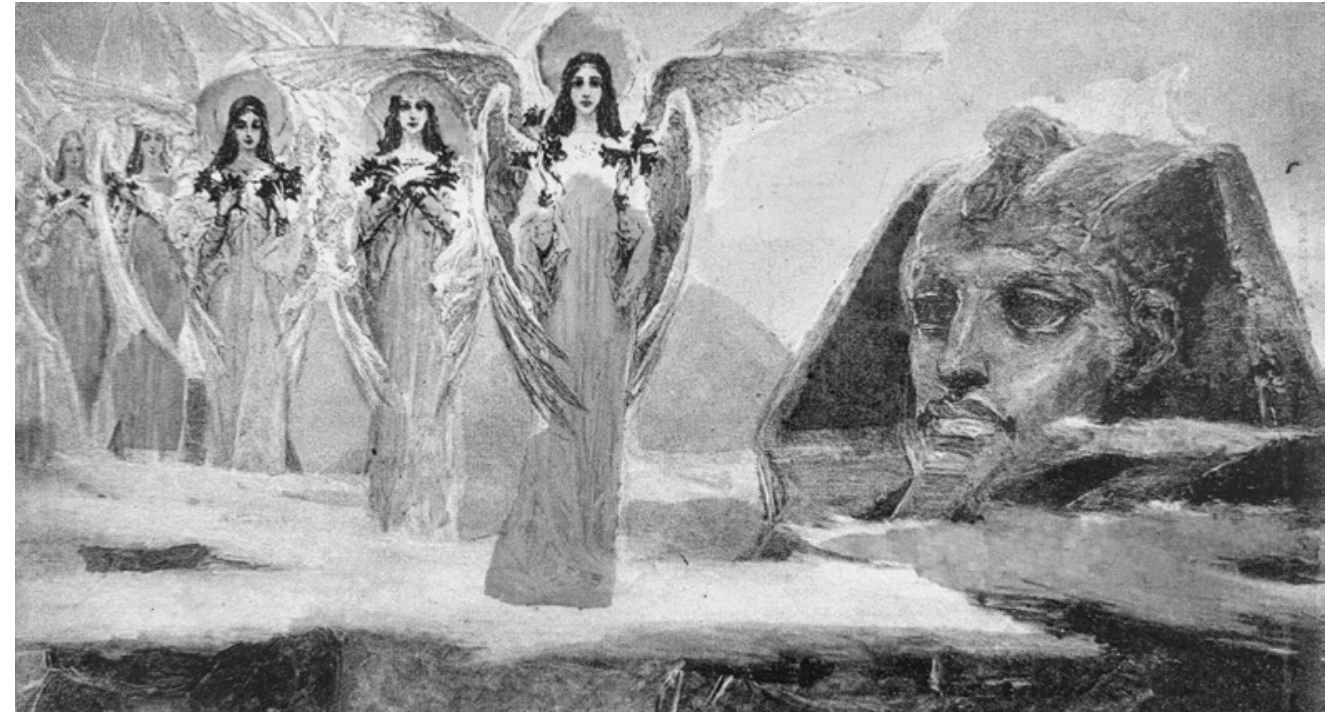

4. Kotarbinski W.

Avantgarde.

Date unknown 


\author{
5. Kotarbinski W. \\ The Victim of the Nile. \\ Date unknown
}

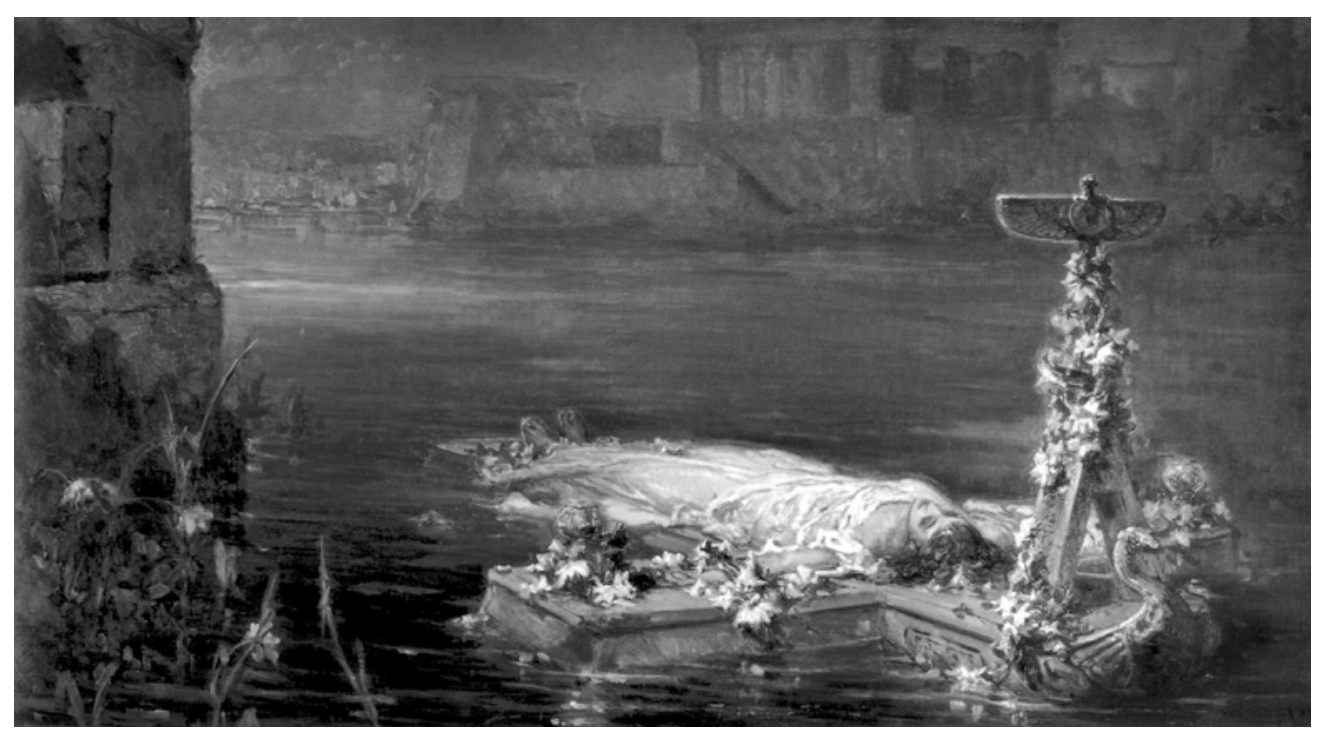

the prism of symbolism and decadence, which enabled combining the historical method with religious mysticism.

For example, in the painting "Moses", the figure of the Pharaoh's daughter is depicted not in the habitual view of a high society woman; it represents an allusion to the sublime and sensual image of the Virgin Mary at the moment when she received the Glad Tidings, indicated by the slight tilt of her head, and the position of her hands (figs. 1, 2). Moreover, the Egyptian princess stands surrounded by lotus flowers, the symbolic meaning of which in Eastern mythopoetics reveals many common aspects with a lily in the Christian tradition, since " $<\ldots$. gods, especially in Egypt and India, come from the lotus flower" [5, p. 202]. Consequently, this floral motif, similar to the lily, can represent the virgin image of the Mother Goddess.

On his two other paintings, "Angels of the Pyramids" (fig. 3) and "Avant-garde" (fig. 4), W. Kotarbinski depicted the collapse of the ancient Egyptian cosmogony and the new Christian worldview. For example, his symbolic compositions represent the cultural paradigm fracture that occurred between the $19^{\text {th }}$ and the $20^{\text {th }}$ centuries, when the old system of spiritual values lost its actuality and required updated worldview attitudes. However, similar to Christianity, that first had to interact with the remains of the ancient Egyptian legacy, new cultural traditions that were formed in fin de siècle were genetically tied to the previous ones.

The subject of death that was a core motif of the decadence art, was not left unattended by the artist in his Egyptian cycle. For example, his painting "The Victim of the Nile" (fig. 5) illustrates the times of the emperor Nero when Christians were suppressed and "crucified or burnt" [13, p. 48]. Its entourage is created by a veduta with dire view with ruins, as a symbol of the death irreversibility. All this is covered with fog which " $<\ldots>$ creates a phantom image, expands the contrast of the reality, the mystic, and the fancy" [4, p. 6]. Consequently, it should be noted that the oriental motifs of this painting have an underlayer, the reflections of two typical iconographic decadent subjects, "Elaine" from a painting by Toby Edward Rosenthal» (1874) and "Ophelia" by John Everett Millais (1852) [12, p. 236].

A creepy and macabre painting "Dream. Daughter of Cairo" (fig. 6) also tells the story of the Egyptian Christian martyr who was decapitated on the votive altar. The outline of her head tied to the hand with hair repeats the silhouette
6. Kotarbinski W. Dream. Daughter of Cairo. Date unknown

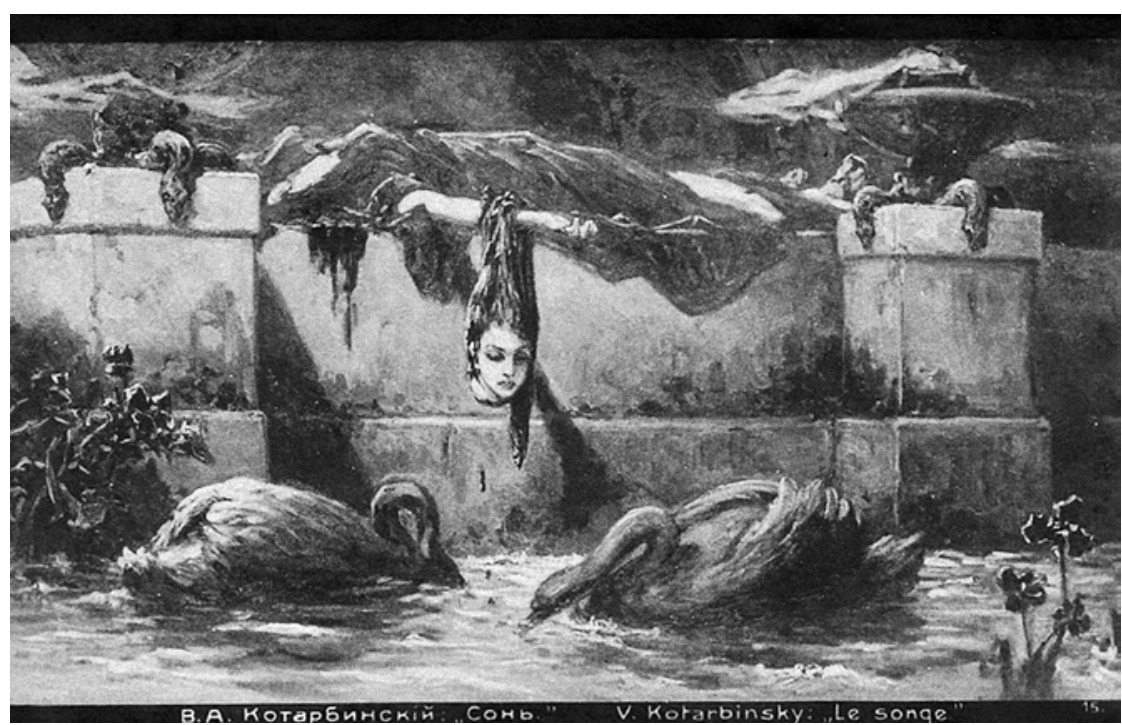



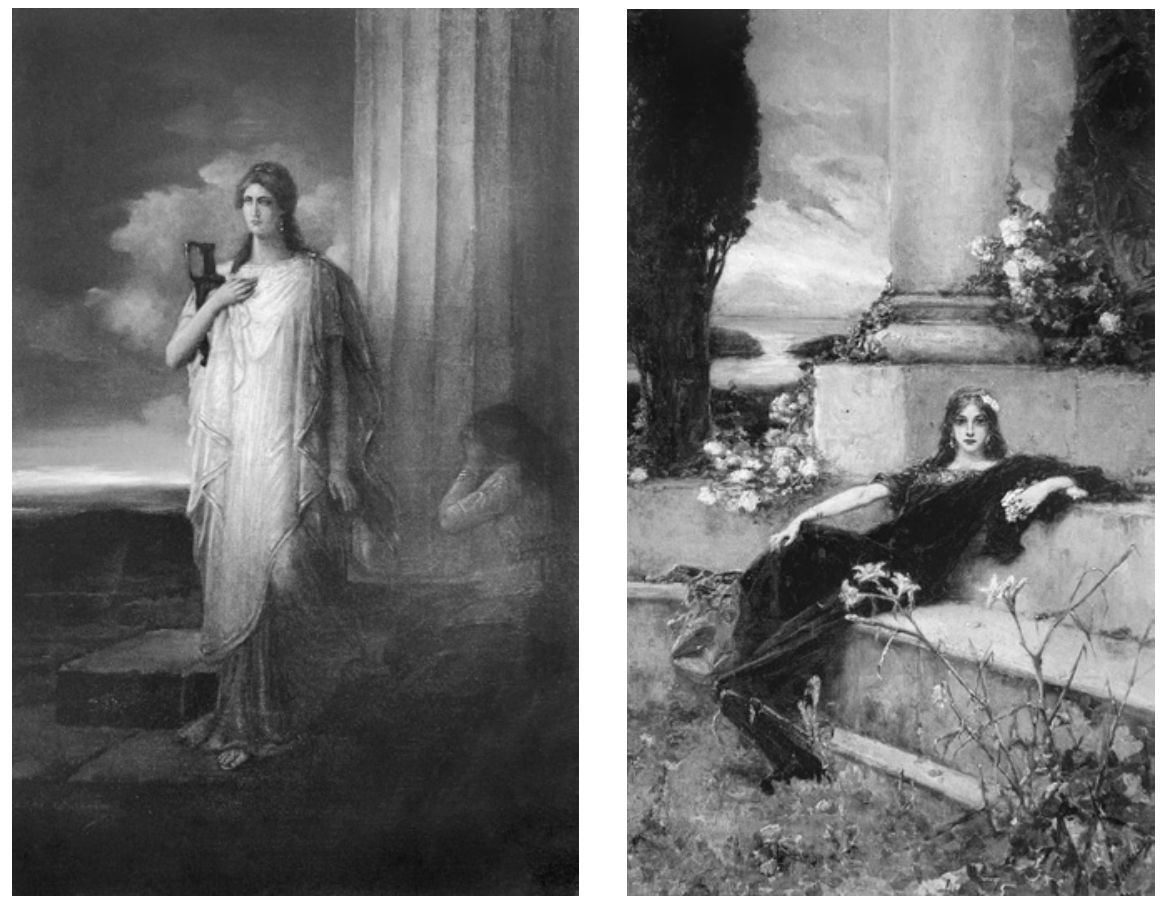

7. Kotarbinskyi W. The Greek Woman. Date unknown

8. Kotarbinskyi W. Evening. Pensive One. Circa 1900

of the swans depicted to the composition fore. In this case, it can be interpreted from a Christian point of view as a symbol of the dying swan song and meekness. At this, the legs of snake-shaped vases, situated on both sides of the altar, symbolize the tempting evil, which tempts the martyr to deny her faith till the last breath.

Merely academic paintings of drawing-room sense in the art of W. Kotarbinski are mostly related to antique subjects. Such works include the following paintings: "Two Roman Women”, “The Greek Woman” (fig. 7), "Evening. The Pensive One” (fig. 8), "Antique Girls” (fig. 9), "By the Altar", "Twilight", "Morning Silence". The aforementioned paintings are of the relatively chamber nature, that complied with the mundane-lyrical plot. They immerse

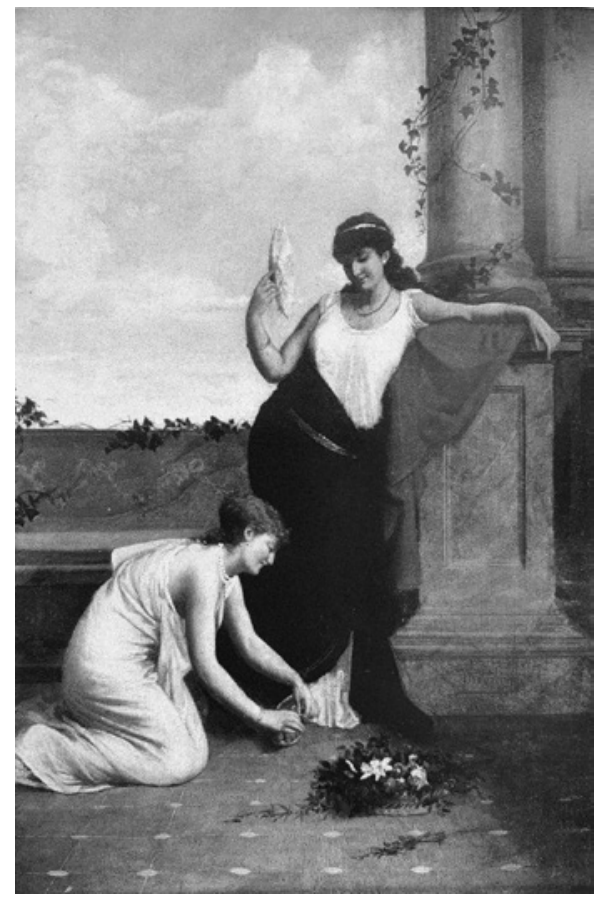

a spectator into the idealistic world of Greek and Roman culture. Since, according to the fine art expert O.V. Nesterova, in the late $19^{\text {th }}$ century, "academic art gradually becomes the means of life decoration and the reason for commerce" [8, p. 17]. Due to this, elegy motives and images have always been in special demand among the representatives of the bourgeoisie.

In the center of the master's antique painting, there is a refined, somewhat cold and disengaged feminine beauty reigned. The heroines of W. Kotarbinski remind the ancient sculptures with the idealized unfaded appearance. The compositional and coloristic principles used by the artist for the above canvases conformed to the academic tradition completely. For example, the main figures, highlighted, were the most located in the composition center, and the preference was given to the tuneful hue and decorative distinctiveness of details.

Conclusions. Therefore, the Egyptian and the antique subjects in the works of W. Kotarbinski brightly illustrate the impact of the historical method and eclectic trends on the development of new art trends in art in late $19^{\text {th }}$ through the early $20^{\text {th }}$ centuries. In the syncretic nature of this artist's works, one can see the interpretation of the certain qualities inherent to the fin de siècle, in particular, the feeling of fear, the predestination of mankind and spiritual apathy, on the one part, and desperate search of spiritual landmarks attempts to escape the reality into the artificial idealized world of beauty and harmony of drawing-room academism, decadence and symbolism, on the other part. 


\section{$\Lambda$ ітература}

1. Валери П. Об искусстве. Москва: Искусство, 1993. 512 с.

2. Груздева Е. Ю. Изучение культуры Аревнего Египта в России на рубеже XIX-XX века / Вестник КГУ им. Н.А. Некрасова. 2009. № 4. C. 275-278.

3. Вільгельм Котарбінський: Альбом. Київ: Укр. письменник, Укр. пропімеї, 2014. 800 с.

4. Кружкова М.І., Марініна О. Ю. Вільгельм Олександрович Котарбінський (1849-1921). Живопис і графіка з музеїв України та приватних колекцій Києва. Київ: Бібліотека українського мистецтва, 2010. 39 с.

5. Малетинский Е.М. Поэтика мифа. Москва: АСТ, 2006. 406 с.

6. Матье М.Э. Искусство Аревнего Египта. Москва: Искусство, $1961.606 \mathrm{c}$.

7. Мережковский А. Мистическое Авижение. URL: http://dugward. ru/library/merejkovskiy/merejkovskiy_misticheskoe_dvijenie.htm (Аата обращения: 08.03.2020).

8. Нестерова Е. В. ПозАний академизм и салон в русской живописи второй половины XIX века: автореферат Аис. ... А-ра искусствоведения: 17.00.04 / Санкт-Петерб. гос. академ. ин-т живописи, скульптуры и архитектуры им. И.Е. Репина. Санкт-Петербург, 2004.32 c

9. Полевой В. М. Искусство Греции: Аревний мир. Москва: Искусство, 1970. 327 с.

10. Савищька $\Lambda$. $\Lambda$. Геній, котрий знав що робить // Вільгельм Котарбінський: Альбом. Київ: Укр. письменник, Укр. пропімеї, 2014. С. 15-34.

11. Савицька $\Lambda$. $\Lambda$. Вільгельм Котарбінський у мистецтві свого часу // Хроніка 2000. Україна - Польща: діалог упродовж тисячоліть. 2009. № 80. С. 562-587.

12. Сосік О.А. Мотив потопельника у художніх творах доби fin de siècle // Вісник КНУКіМ. Серія мистецтвознавство. 2019. № 41. C. 233-240. DOI: 10.31866/2410-1176.41.2019.188705

13. Тациит П. К. Анналы. История. Москва: АСТ, 2005. 832 с.

14. Тураев Б. А. История Аревнего востока. Москва: Книга по требованию, 2012.308 c.

15. Всеобщая история искусств: в 6 т. / под реА. А.А. Чегодаева. Москва: Искусство, 1965. Т. 1. Кн. 1: Искусство Аревнего мира. 865 с. 16. Школьна О.В. Арабське мистецтво та сучасна його специфіка вивчення // Художня культура. Актуальні проблеми. 2017. № 13. C. 119-127. DOI: https://doi.org/10.31500 /1992-5514. 13.2017.134017

\section{References}

1. Valeri P. Ob iskusstve. Moskva: Iskusstvo, 1993. $512 \mathrm{s.}$

2. Gruzdeva E. Yu. Izuchenie kulturyi drevnego Egipta v Rossii na rubezhe XIX-XX veka // Vestnik KGU im. N. A. Nekrasova. 2009. \# 4. S. 275-278.

3. Vilhelm Kotarbinskyi: Albom. Kyiv: Ukr. pysmennyk, Ukr. propilei, 2014. $800 \mathrm{~s}$.

4. Kruzhkova M. I., Marinina O. Yu. Vilhelm Oleksandrovych Kotarbinskyi (1849-1921). Zhyvopys i hrafika z muzeiv Ukrainy ta pryvatnykh kolektsii Kyieva. Kyiv: Biblioteka ukrainskoho mystetstva, $2010.39 \mathrm{~s}$.

5. Maletinskiy E. M. Poetika mifa. Moskva: AST, 2006. 406 s.

6. Mate M.E. Iskusstvo Drevnego Egipta. Moskva: Iskusstvo, 1961. $606 \mathrm{~s}$.

7. Merezhkovskiy D. Misticheskoe dvizhenie. URL: http://dugward. ru/library/merejkovskiy/merejkovskiy_misticheskoe_dvijenie.html (data obrascheniya: 08.03.2020).

8. Nesterova E. V. Pozdniy akademizm i salon v russkoy zhivopisi vtoroy polovinyi XIX veka: avtoreferat dis. ... d-ra iskusstvovedeniya: 17.00.04 / Sankt-Peterb. gos. akadem. in-t zhivopisi, skulpturyi i arhitekturyi im. I.E. Repina. Sankt-Peterburg, 2004. 32 s.

9. Polevoy V.M. Iskusstvo Gretsii: Drevniy mir. Moskva: Iskusstvo, $1970.327 \mathrm{~s}$.

10. Savytska L. L. Henii, kotryi znav shcho robyt // Vilhelm Kotarbinskyi: Albom. Kyiv: Ukr. pysmennyk, Ukr. propilei, 2014. S. 15-34. 11. Savytska L.L. Vilhelm Kotarbinskyi u mystetstvi svoho chasu // Khronika 2000. Ukraina — Polshcha: dialoh uprodovzh tysiacholit. 2009. \# 80. S. 562-587.

12. Sosik O.D. Motyv potopelnyka u khudozhnikh tvorakh doby fin de siècle // Visnyk KNUKiM. Seriia mystetstvoznavstvo. 2019. \# 41. S. 233-240. DOI: 10.31866/2410-1176.41.2019.188705

13. Tatsit P.K. Annalyi. Istoriya. Moskva: AST, 2005. $832 \mathrm{~s}$.

14. Turaev B. A. Istoriya drevnego vostoka. Moskva: Kniga po trebovaniyu, $2012.308 \mathrm{~s}$.

15. Vseobschaya istoriya iskusstv: v 6 t. / pod red. A. D. Chegodaeva. Moskva: Iskusstvo, 1965. T. 1. Kn. 1: Iskusstvo Drevnego mira. 865 s.

16. Shkolna O.V. Arabske mystetstvo ta suchasna yoho spetsyfika vyvchennia // Khudozhnia kultura. Aktualni problemy. 2017. \# 13. S. 119-127. DOI: https://doi.org/10.31500/1992-5514.13.2017. 134017 


\section{Сосік O.}

Аавньоєгипетські й античні візії у творчому доробку Вільгельма Котарбінського

Анотація. Розглянуто звернення українського художника польського походження Вільгельма Котарбінського Ао Аавньоєгипетських й античних візій впродовж кінця XIX — початку XX століть. На прикладі згаданих тем окреслено сутність стилістичних трансформацій творчості художника в період поширення мистецьких віянь, пов'язаних із салонним академізмом, декадансом і символізмом. Зазначено, що класичні твори «на антик» та дотичні до них елементи давньоєгипетського мистецтва доби еллінізму, які увійшли до скарбниці світового мистецтва в періоА ампіру, скмали основу художної мови Аоби історизму, коли були вАруге пережиті та переосмислені митцями, що пройшли академічну фахову освіту. Ці ж добре розучені першоелементи надалі стали художнім матеріалом, крізь призму якого митці «проживали» новітні фінософсько-естетичні враження й вклаАали у них нові нашарування смислів.

К^ючові слова: історизм, єгипетське й античне мистецтво, академізм, декаданс, символізм, творчість В. Котарбінського, орієнталізм, античність.

Сосик $\mathrm{O}$.

Аревнеегипесткие и античные визии в творческом наследии Вимьгемьма Котарбинского

Аннотация. Рассмотрено обращение украинского художника польского происхождения Вильгельма Котарбинского к Аревнеегипетским и античным визиям на протяжении конца XIX — начала XX веков. На примере упомянутых тем обозначена сущность стилистических трансформаций творчества художника в периоА распространения художественных веяний, связанных с салонным академизмом, декадансом и символизмом. Отмечено, что классические произведения «на антик» и близкие к ним эмементы Аревнеегипетского искусства эпохи эмминизма, которые вошли в сокровищницу мирового искусства в периоА ампира, составили основу художественной речи эпохи историзма. Эти хорошо разученные первоэлементы в Аальнейшем стали художественным материалом, сквозь призму которого художники «проживали» новейшие философско-эстетические впечатления и вкладывали в них новые наслоения смыслов.

Ключевые слова: историзм, египетское и античное искусство, академизм, декаданс, символизм, творчество В. Котарбинского, ориентализм, античность. 